\title{
Five Pictures of My Son
}

\author{
Rita Malenczyk
}

\section{This essay addresses suicide and family grief and may be emotionally upsetting to some readers.}

Rita Malenczyk is professor of English and director of the writing program and writing center at Eastern Connecticut State University. Her scholarship and other writing has appeared in numerous journals and edited collections. She has edited or co-edited three books, including $A$ Rhetoric for Writing Program Administrators (Parlor Press, 2016) and, with Susan Miller-Cochran, Elizabeth Wardle, and Kathleen Blake Yancey, Composition, Rhetoric, and Disciplinarity (Utah State University Press, 2018).

I

$\mathrm{n}$ the photo my son Pete lifts the red racing bike above his head, face toward the sky, strength in his muscles, victory in his pose. The photo closes the story the Key West TV station ran about his bike ride: he pedaled 200 miles in 24 hours from Boca Raton to the southernmost point of the Keys to raise money for mental health, suicide prevention, and youth hockey. You can see, on his right arm, the tattoo he got in memory of a friend who died unexpectedly after a seizure. A tattoo for his brother Nick is on his left wrist-the number 20 , along with the time shown on the clock when Nick scored the winning goal in the state championship game. Pete also sports the number 20 on the back of his bike jersey. That does not show up in the picture.

"What do we need it for?" my husband, Bruce, asked the funeral director when she said the death certificate was included in the price of the package. Apparently you need it for all sorts of things: taking someone off your cell-phone contract, for instance. Or off your health insurance-though the person in human resources eventually said, after l'd faxed it to her, that it was okay, she'd found the obituary and would use that instead. I had gone to great lengths to avoid looking at the certificate, copying it face down on the English Department copier, turning my head away while the machine did its work. I made sure to keep it folded up when I brought it to the cell phone company to turn in Nick's phone and ask that he be taken off our plan. It was Bruce who brought the laptop to donate to the high school, giving it directly to the superintendent, asking that it be wiped clean and refurbished so another student could use it. The laptop was a recent model; Nick had graduated less than two years earlier.

I hadn't taught first-year students in a while; my department chair and dean reassigned the writing class I was supposed to teach that January, and after that I happened to have other courses assigned: a sophomore-level course, my senior seminar. But I wanted to return to teaching first-years, so there I was in fall 2020, trying to resume my life as it had been before. The class was socially distanced because of the pandemic; my students were separated, six feet apart, in a cavernous computer lab that made

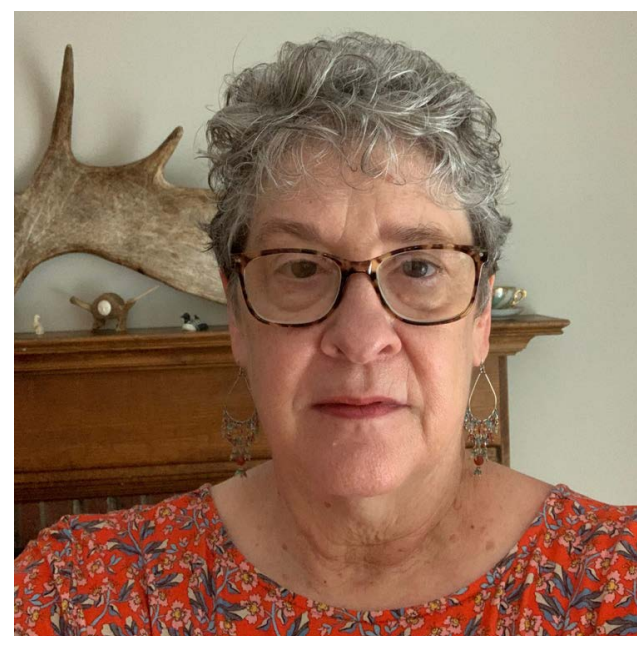

\section{Abstract}

It's hard for me to talk in any kind of brief, definitive way about what this essay is. If pressed (which I sort of am now) l'd say that it's a reflection on coming to terms with what is possibly the most terrible thing that can happen to a parent, and doing so while one is a teacher, scholar, and writer. It is also, for me, a way of moving forward, of memorializing my son while trying to find meaning in the things I've always done but which have changed in their significance now, in ways I'm not yet sure I can name.

\section{Keywords}

suicide, teaching, writing 
discussion pretty much impossible. There was no way I could set up small-group discussion, walk around the classroom, comment on students' writing and answer questions as they composed at the computers. Yet I needed them to know that I was available, that I wanted them to be writers just as I wanted to go back to writing. So in the spring I switched to a fully online format where at least I could see them face to face on Zoom, schedule individual chats and talk to them about their plans for their essays before they began to write-give them the kind of feedback l'd always liked as a writer. Because ever since Nick, l've been afraid all these kids will die.

\section{$* * *$}

In the prom-night photo, Banzai sits on the floor and looks up at Nick adoringly as only dogs can do, probably hoping for food. (The photo was taken in the kitchen.) Nick's a senior, so it's his last prom. He smiles with both his mouth and his eyes; he wears a close-fitting black tux. He hadn't yet grown the beard. Shortly after the photo was taken he would go to the green, our New England town's gathering place, for more photos. He went with his friends. I followed later to take my own pictures, but when I got there, one of those friends said he had left without telling them where he was going. Frightened-because by this time I was alarmed by odd behavior from Nick-I headed back home, but he wasn't there. I drove frantically back to the green hoping he had returned; a state trooper was nasty to me for disrupting the flow of traffic. But Nick was in fact there, and I managed to get another photo of him: this time with his date, a lovely girl named Rachel, whose long blonde hair was swept up in a bun and who was wearing a real stunner of a dress-not the brightly colored sequin-y things so common now among prom-going youth but rather an elegant black dress with delicate white trim. She and Nick look like movie stars. There's a soft breeze, and Nick is brushing his hair back to keep it out of his face.

I had been working on an edited collection during 2018. I don't remember now what phase it was in when the new year came around, but I emailed the acquisitions editor, explained what had happened, told her I needed more time and that I honestly didn't know how much time that would be. She understood. So did the contributors. I did have to write a few letters for those contributors up for promotion or tenure, telling department chairs the collection was delayed "because of a tragic death in my immediate family" but that a university press had expressed strong interest in it and had asked to see the manuscript.

With some exceptions, amateur hockey rinks are fairly predictable places: dads stand along the boards, often in groups, analyzing past and current games. They often have unrealistic expectations of their own and others' kids, which are expressed in comments during the games. Moms have those expectations too (I knew one who was thrown out of numerous rinks), yet they typically sit in or patrol the stands, sometimes watching smaller children and making sure they don't wreak too much havoc. Some, both moms and dads, took photos at high school games; some were really good, professional quality. In one of them, Nick-number 20-shoots at the net, and the photo captures the impossible convex bend of his stick as he fires. He practiced almost every day in the driveway; he made all state twice. Between the two of them, Pete and Nick helped win a state championship for the high-school team, Pete scoring four of the five goals, Nick scoring the other and assisting three of Pete's. The bend of his stick demonstrates Nick's power, his grace, the beauty of how he could weave and move the puck and finish the goal, sometimes the game.

On January 8, I had called his therapists because I was concerned about his state of mind; they had, however, already done a suicide evaluation and deemed him safe. When I talked to Nick later that afternoon, he told me he planned to volunteer at the institute where he was being treated, doing various types of work. This was something the therapists had been trying to get him to do, to be more active. I was thrilled. The next morning I woke up to the sound of our oldest son, Sam, screaming for Bruce: "Dad, Dad," and Bruce ran to the basement and began screaming too. I had never heard men scream before.

\section{$* * *$}

Calling Pete later that morning was, up until that point, the hardest thing I had ever done.

$$
* * *
$$

Sometimes I teach a course in rhetorics and narratives of crime. When the call for abstracts came out for the next volume of a new journal out of Edinburgh University Press, Crime Fiction Studies, I sent an abstract of one of my recent conference papers. I thought I should get back to some kind of normal. This was in early 2020 . The abstract was accepted, a full essay was requested. I banged out the essay, forced myself to sit at the computer for an hour each day until it was finished. It came back in July from peer review with requests for major revision. I told the editors I couldn't do it, that I didn't have the head space, and I told them why. I figured I would never write that essay; which was a shame, as it was a pretty good idea.

$$
\text { *** }
$$

Not all the dreams are bad. In the one I had about two weeks ago, Nick walked in from somewhere looking just like himself, smiling, happy like I hadn't seen him happy since he was a little boy. I hugged him and said something like "Nick, you're here, it's really you," and he said yeah, and my husband came into the dream and I think I said something like "Bruce, Nick is back." And he was, he was back. And he was okay. And I wanted to prove he was real, not just a figment of Bruce's and my imagination, so when my friends John and Melissa showed up in the dream, I said, "Go look. Tell me if you see Nick." They agreed he was back, he was real. "He 
looks like an angel," Bruce said, though we both knew there were no such things as angels, and I think we knew he wouldn't stay but it was good to know he was there, that he wasn't gone gone. Eventually he became himself as a child-it was something that happened gradually. I don't remember anything else. I woke up without being able to say goodbye to either the adult or the child.

John, the town fire chief, took the dog to the pound for a day until everyone official — the cops, the medical examiner, the chaplainhad done their duty. Banzai is a herding dog and couldn't handle the heavy black boots walking in and out the door, the sirens outside, the ME coming up from the basement wiping tears from her eyes. Or the neighbors on their way to work who kept stopping at the end of the driveway to ask what had happened. John also took our son Sam to his girlfriend's house so he could be with her, called Sam's employers to explain the situation, called Sam the next morning to see if he needed anything. Later that day he brought some food and a cyclamen plant. The plant still thrives on our bedroom windowsill. John also took care of selling Nick's car for us; for weeks afterward he would sometimes stop by to see how we were doing. I would usually just cry.

The same week the very good reviews of the edited collection came back, I got an email from one of the Crime Fiction Studies editors asking if l'd thought further about revising that essay? They were preparing for two new open issues and wondered if l'd had the chance to work on it. I wrote back. We agreed I could have until late August to make revisions if I wanted it in one of the upcoming issues-which, the editor said, should certainly be doable because the essay was "pretty darn good already." I've been toying with ideas, making notes, thinking about how I might handle this a little at a time, wondering if I can.

Jeff, the chaplain who came to the house that morning, was the pastor of the local Congregational church. I hadn't wanted to talk with him because after an upbringing in the Catholic church, I was done with religion, but all he did was sit, and listen, and eventually I started talking about what I wanted to do in Nick's memory. We held the funeral at Jeff's church, with him officiating, telling the gathered crowd he couldn't say any easy words that would take away their pain or persuade them Nick's death was God's will-because, he said, "No God I believe in would willingly wrest a 19-year-old man from this earth." There were two other suicides of young men in our town the same year Nick died. Afterward-several months afterward-I joined the church and, together with Jeff and others, started holding a reading group to raise awareness of mental-health issues. One has to start somewhere. Or move forward, somehow.
Sometimes I go into Nick's old room and look at the stuff we collected before, during, and after the funeral. The sympathy cards people sent us; the tags from the flowers people sent to the wake; the big old stuffed dog Nick slept with when he was little; his leather wallet; his car keys; the tiny jacket he wore when he started playing youth hockey. His senior photo: dressed in a light blue polo shirt and (probably) khakis, hair neatly trimmed, he sports the crooked smile he inherited from my Aunt Mae. I have that smile too, as does Pete. We don't know what to call that room now.

We got a lot of food when the police and the ambulance left, when the word got out through social media, when Nick's old high-school hockey team played a tribute game for him that was all over Twitter. People brought casseroles to our house, sent sympathy boxes full of snacks: peanuts, cheese sticks, sausage. Coffee cake, and coffee. One of my friends made marinated pork tenderloin and squash soup. I still think about what we would've done if it hadn't been cold outside, since there was way too much to fit in our refrigerator, and we had to put most of it in the garage. We also got some other tokens: a religious pamphlet about how to survive a suicide loss; several candles; a white woolen pillow in the shape of a heart. A book called Tear Soup that I didn't even bother to crack open. One family gave us a set of wind chimes, and we hung them on the pergola on our deck. I wait now for the warm weather so I can sit outside where they are-because if I look and listen really hard, I can see them dance, hear them call his name.

(for Nick, 3/4/99-1/9/19)

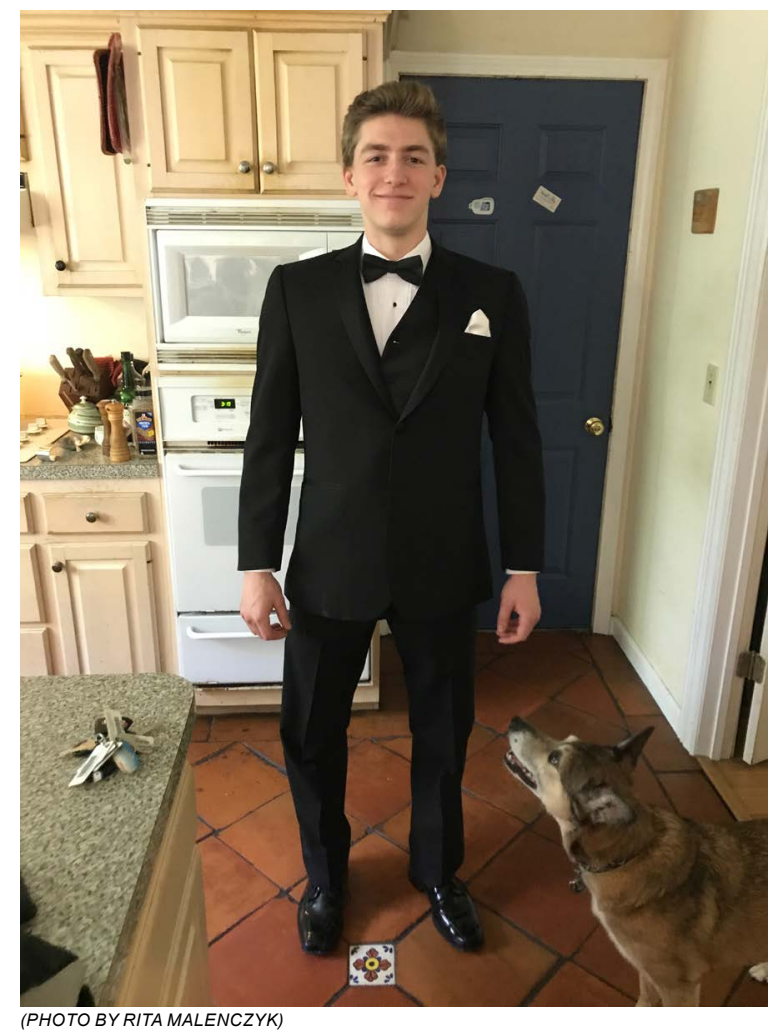

